\title{
Differential Accumulation of Metabolites in Suaeda Species Provides New Insights into Abiotic Stress Tolerance in $\mathrm{C}_{4}$-Halophytic Species in Elevated $\mathrm{CO}_{2}$ Conditions
}

\author{
Sonam Yadav ${ }^{1}$, Hosam O. Elansary ${ }^{2,3, *(\mathbb{D})}$, Mohamed A. Mattar ${ }^{4}$, Khalid M. Elhindi ${ }^{2,5}$, Majed A. Alotaibi ${ }^{2}$ and \\ Avinash Mishra ${ }^{1, *(\mathbb{D})}$ \\ 1 Division of Applied Phycology and Biotechnology, CSIR-Central Salt and Marine Chemicals Research Institute, \\ G. B. Marg, Bhavnagar 364002, India; sonam_yadav11@yahoo.com \\ 2 Plant Production Department, College of Food and Agricultural Sciences, King Saud University, \\ Riyadh 11451, Saudi Arabia; kelhindi@ksu.edu.sa (K.M.E.); malotaibia@ksu.edu.sa (M.A.A.) \\ 3 Floriculture, Ornamental Horticulture, and Garden Design Department, Faculty of Agriculture (El-Shatby), \\ Alexandria University, Alexandria 21545, Egypt \\ 4 Agricultural Engineering Department, College of Food and Agriculture Sciences, King Saud University, \\ Riyadh 11451, Saudi Arabia; mmattar@ksu.edu.sa \\ 5 Department of Vegetable and Floriculture, Faculty of Agriculture, Mansoura University, \\ Mansoura 35516, Egypt \\ * Correspondence: helansary@ksu.edu.sa (H.O.E.); avinash@csmcri.res.in (A.M.)
}

\section{check for}

updates

Citation: Yadav, S.; Elansary, H.O.; Mattar, M.A.; M. Elhindi, K.; A. Alotaibi, M.; Mishra, A. Differential Accumulation of Metabolites in Suaeda Species Provides New Insights into Abiotic Stress Tolerance in $\mathrm{C}_{4}$-Halophytic Species in Elevated $\mathrm{CO}_{2}$ Conditions. Agronomy 2021, 11, 131. https://doi.org/10.3390/ agronomy11010131

Received: 13 November 2020 Accepted: 8 January 2021 Published: 11 January 2021

Publisher's Note: MDPI stays neutral with regard to jurisdictional clai$\mathrm{ms}$ in published maps and institutional affiliations.

Copyright: () 2021 by the authors. Licensee MDPI, Basel, Switzerland. This article is an open access article distributed under the terms and conditions of the Creative Commons Attribution (CC BY) license (https:// creativecommons.org/licenses/by/ $4.0 /)$.

\begin{abstract}
Halophytic plants can adapt to grow and thrive in highly saline conditions. Suaeda species are annual halophytes with high salt tolerance and are most suitable in the restoration of salinized or contaminated saline land and as food, forage, medicine, and bioenergy. In this study, we comprehensively analyzed the different metabolic responses of Suaeda species under salt and drought stress at ambient and elevated $\mathrm{CO}_{2}$ conditions. Seedlings of Suaeda species were treated with $500 \mathrm{mM} \mathrm{NaCl}$ and $5 \%$ of polyethylene glycol under elevated $\mathrm{CO}_{2}$ stress conditions for $24 \mathrm{~h}$. Then, widely untargeted metabolites were detected by gas chromatography-mass spectrometry. Different metabolites involved in amino acid metabolism, glycolysis, photorespiration, and tricarboxylic acid cycle were quantitatively determined after stress treatments. A total of 61 primary metabolites were annotated. Different treatments increased the contents of certain metabolites, such as amino acids, sugars, and organic acids, as well as some antioxidants, such as quininic acid, kaempferol, and melatonin. These substances may be correlated with osmotic tolerance, increased antioxidant activity, and medical and nutritional value in the species. This study suggests that various metabolites differentially accumulated in $\mathrm{C}_{4}$ Suaeda species under varying stress conditions. Furthermore, this work provides new insights into the key secondary metabolite pathway involved in stress tolerance.
\end{abstract}

Keywords: abiotic stress; $\mathrm{C}_{4}$ plants; drought; elevated $\mathrm{CO}_{2}$; halophyte; salinity

\section{Introduction}

Plants are affected continuously by various environments, such as abiotic and biotic factors, although the consequences of these factors on the plant system depends on their intensity or quantity. Abiotic stresses, including elevated $\mathrm{CO}_{2}$, high temperature, lower precipitation, cold, salinity, drought, heavy metals, and different oxidative stress, are the primary sources of the comprehensive loss of agricultural productivity, total biomass yield, and crop quality [1-3]. Elevated $\mathrm{CO}_{2}$ increases the net photosynthesis and water use efficiency in $\mathrm{C}_{3}$ and $\mathrm{C}_{4}$ plants, and this may also compensate for savings in growth and plant yield under drought stress [4-7]. $C_{3}$ plants were previously reported to increase their net photosynthesis rate and growth by about $35 \%$ under enhanced $\mathrm{CO}_{2}$ conditions, stimulating biomass production $[8,9]$. Elevated $\mathrm{CO}_{2}$ can also diminish the effects of abiotic stresses on plants, including heat, ozone, and drought [10]. Particularly, the mitigation 
of drought stress responses is triggered by stomatal factors, including increased stomatal closure and reduced stomatal density, improving the water use efficiency in plants [11,12].

Drought and salinity stresses are severe threats to plant growth and photosynthesis metabolism due to recurring global climate changes. Photosynthesis inhibition, alterations of cell metabolism, and deterioration of proteins and membranes are commonly detected under stress conditions. Worldwide, salinization is a significant problem. Approximately $2 \%$ of total land is affected by salinity, and 45 million ha of the available 230 million ha of irrigated land is salt-affected [13]. To cope with these environmental changes, plants induce numerous physiological, biochemical, and molecular changes by activating corresponding key genes essential for plant defense mechanisms [14]. Recent studies have revealed that plants respond within seconds to minutes to different stress stimuli through different physiological, biochemical, metabolic, and molecular networks [15]. Some rapid responses include electrolyte leakage, membrane stability, antioxidant enzyme activities, stomatal conductance changes, quenching of reactive oxygen species (ROS), accumulation of osmolytes, and expression of key genes involved in signal pathways and defense systems [15]. Therefore, elevated ROS levels and imbalances in redox homeostasis lead to changes in metabolites, creating oxidative stress [16]. However, understanding the metabolic responses in plant systems under salt and drought effects and under predicted future climate conditions could help identify new strategies to improve stress tolerance.

Halophytes have a remarkable ability to tolerate high salinity and adverse drought stress during their lifespan [17]. Taxa with $\mathrm{C}_{4}$ carbon fixation appear to be overrepresented among halophytes. They have evolved from $C_{3}$ ancestors accordingly to survive in these environmental stress conditions. Further, they (halophytes) develop efficient features, such as a high photosynthesis rate, uptake or elimination of selective ions, synthesis of the enzymatic and non-enzymatic antioxidant defense system, alterations in metabolite levels, and high gene expression compared to glycophytes, in order to cope with induced stress through environmental changes $[18,19]$. Previous studies have demonstrated that plants accumulate low molecular weight organic compounds, including sugars, proline, and glycine betaine, and act as an osmoprotectant under salt stress in halophytes [20]. Halophytes are most suitable for the restoration of salinized or contaminated saline land for removing heavy metals from saline soils. They can be utilized as food, forage, medicine, and bioenergy [21-24]. Halophytes are a good source of salt-resistant genes [25-36] and promoters [37-40].

Due to favorable climate and edaphic conditions, one of the world's best salt marsh flora occurs along a $5700 \mathrm{~km}$ stretch of coastline in India and Saudi Arabia. The higher plants present in this vegetation are mangroves, halophytes, and sea grasses. An extreme halophyte, Suaeda, an annual plant, also known as seep weed or sea blite, belongs to the Amaranthaceae family, is widely dispersed on India's east and west coasts, and completes its life cycle in saltmarsh areas, such as coastal and intertidal regions near estuaries. Both Suaeda monoica and Suaeda fruticosa possess unique $\mathrm{C}_{4}$ carbon assimilation, in which the photosynthesis pathway occurs within a single elongated chlorenchyma cell [41]. The optimal growth range for both Suaeda species is between 200 and $500 \mathrm{mM} \mathrm{NaCl}$ [42]. To deal with this stressed environment and to conserve water accessibility, halophytes accumulate compatible solutes, such as glycine betaine, sucrose, and proline, in vacuoles together, maintaining osmotic potential via the uptake of osmotically active ions [43]. Naturally, $C_{4}$ plants have a higher photosynthetic rate and water use efficiency compared to $C_{3}$ plants. Enzymes involved in $C_{4}$ carbon assimilation also play a fundamental role in plant defense responses under different abiotic and biotic stress conditions $[44,45]$.

Metabolite profiling is one of the efficient and quantitative methodologies that provide a functional analysis approach in order to connect physiological and metabolic responses to phenotypic and genetic information [46-51]. Such technologies can be used to better understand the mechanisms underpinning plant responses to global climate change [52,53]. A metabolomics study estimating the nutritional value examined whether these metabolites are associated with stress tolerance $[54,55]$. This technique can be used to provide 
perceptions into metabolic pathways and instabilities during stress; therefore, it can reveal targets for improving plant performance in the future. A previous omics study showed that deviations in the nature and amount of metabolites can show how the plant acclimatizes to environmental changes [56]. Metabolites are anxious under stress conditions, and the plant system needs to regulate the metabolite levels to maintain basal metabolism and reach new homeostasis [57]. Therefore, metabolomics is the most direct tool for studying metabolite changes under different stress conditions [58]. During plant stress, changes in primary metabolites are most prominent and also show a general trend of response to abiotic stress. This involves the accumulation of compatible solutes, such as amino acids, sugars, and sugar alcohols, to cope with osmotic stress [59]. Several reports are available on the metabolic responses of $C_{4}$ plants, while the roles of different amino acids and metabolites of the tricarboxylic acid cycle (TCA) cycle have been evaluated under different abiotic stress treatments in Suaeda species [20,60-64]. Briefly, some specific metabolites and their derivatives, including nucleotides, amino acids, organic acids, lipids, antioxidants such as quercetin, and intermediates of the TCA cycle, increase in Suaeda salsa under salt stress, confirming their role in tolerance $[65,66]$.

Similarly, the concentrations of hexose phosphate, intermediates of the TCA cycle, and osmoprotectant metabolites increase concomitantly with salt concentrations in a salttolerant variety of Hordeum vulgare [67]. Moreover, in Zea mays, a significant accumulation of organic solutes plays an essential role in osmotic stress resistance [68]. Furthermore, metabolites play indispensable roles in stress tolerance $[57,69]$, nitrogen metabolism $[70,71]$, regional differences [72], and phenotypic changes [73]. Interestingly, $\mathrm{C}_{4}$ guinea grasses (Panicum maximum Jacq.) alter their transcript and metabolite profiling associated with environmental response, stomatal function, and secondary metabolism under elevated $\mathrm{CO}_{2}$ and temperature [69]. Overall, previous reports have shown that metabolites play an essential role in providing plant tolerance under different stress conditions.

Previous investigations have proven that S. monoica and S. fruticosa are two Suaeda species that exhibit distinct physiological performance under elevated $\mathrm{CO}_{2}$ stress $[74,75]$. There is an increasing need to investigate and understand plant metabolic responses in terms of biochemical and physiological levels to global climate change or abiotic stress. With a broad objective of assessing how elevated $\mathrm{CO}_{2}$ can mitigate the detrimental effects of plants under stress conditions, this study was carried out to investigate whether these two Suaeda species respond differently under salt and drought stress conditions under ambient and elevated $\mathrm{CO}_{2}$ conditions using metabolites as indicators. Different metabolites involved in amino acid metabolism, glycolysis, photorespiration, and the TCA cycle were quantitatively determined after stress treatments. The effects of elevated $\mathrm{CO}_{2}$ integrated with salt or drought stress on the physiological and metabolic adaptation mechanisms of both Suaeda species were investigated for the first time.

\section{Materials and Methods}

\subsection{Plant Materials and Stress Treatments}

Seeds of $S$. monoica and $S$. fruticosa were germinated in garden soil and irrigated with a half-strength nutrient solution [74]. Seedlings were allowed to grow in a culture room under control conditions with a $12 \mathrm{~h}$ light $/ 12 \mathrm{~h}$ dark cycle at $25{ }^{\circ} \mathrm{C} \pm 2{ }^{\circ} \mathrm{C}$. After 2 months, seedlings were initially cultivated in half-strength Hoagland hydroponic culture medium [76] for 1 month. Three-month-old Suaeda plants were divided into two sets. The first set of plants was shifted to a plant growth chamber (Percival, Iowa, USA) under ambient $\mathrm{CO}_{2}(\sim 400 \mathrm{ppm})$ conditions, then acclimatized plants were subjected to salt $(500 \mathrm{mM} \mathrm{NaCl})$ and osmotic (5\% polyethylene glycol (PEG)) stress for $24 \mathrm{~h}$. The second set of plants was acclimatized in elevated $\mathrm{CO}_{2}(\sim 900 \mathrm{ppm})$ conditions (in a plant growth chamber) followed by stress treatments with salt (500 $\mathrm{mM} \mathrm{NaCl})$ and osmotic $5 \%$ PEG for $24 \mathrm{~h}$. All stress treatments were carried out under plant growth chamber conditions involving a $12 \mathrm{~h}$ light $/ 12 \mathrm{~h}$ dark photoperiod at $25^{\circ} \mathrm{C} \pm 2{ }^{\circ} \mathrm{C}, 1100 \mu \mathrm{mol}$ quantum ${ }^{-2} \mathrm{~s}^{-1}$ light, and $55 \%$ to $60 \%$ relative humidity. Mature fresh leaves of all treated plants and the 
corresponding control plants were harvested, frozen in liquid $\mathrm{N}_{2}$, and stored at $-80{ }^{\circ} \mathrm{C}$ for further analysis.

\subsection{Metabolite Extraction}

Metabolites were extracted from leaves of control and treated plants and analyzed by gas chromatography-mass spectrometry (GC-MS) [77]. Leaf samples ( 0.1 g) were ground into fine powder in liquid $\mathrm{N}_{2}$, then ice-cold $100 \%$ methanol $(0.7 \mathrm{~mL})$ was added for enzyme inactivation, followed by the addition of $30 \mu \mathrm{L}$ adonitol $(0.2 \mathrm{mg} / \mathrm{mL})$ as an internal reference [78]. The samples were mixed by vortexing for $20 \mathrm{~s}$, incubated at $70{ }^{\circ} \mathrm{C}$, sonicated for $10 \mathrm{~min}$ at room temperature, then centrifuged at $10,000 \times g$ for $10 \mathrm{~min}$. A clear solution was transferred into a $2 \mathrm{~mL}$ tube, approximately $325 \mu \mathrm{L}$ chloroform and $700 \mu \mathrm{L}$ water were added, then the samples were mixed thoroughly and centrifuged at $10,000 \times g$ for $5 \mathrm{~min}$ at room temperature. The upper polar phase $(600 \mu \mathrm{L})$ was transferred in a fresh $1.5 \mathrm{~mL}$ tube, dried in a vacuum concentrator (without heating), then stored at $-80{ }^{\circ} \mathrm{C}$ for further analysis. Before derivatization, the samples were again vacuum dried for $30 \mathrm{~min}$, then $60 \mu \mathrm{L}$ methoxyamine hydrochloride $(20 \mathrm{mg} / \mathrm{mL}$ in pyridine $)$ was added, followed by incubation for $2 \mathrm{~h}$ at $37{ }^{\circ} \mathrm{C}$ in shaking conditions. Finally, $130 \mu \mathrm{L}$ $\mathrm{N}$-methyl-N-(trimethylsilyl) trifluoroacetamide was added and incubated for $30 \mathrm{~min}$ at $37^{\circ} \mathrm{C}$. The sample was transferred into glass vials for GC-MS analysis.

\subsection{Metabolite Analysis by GC-MS}

The GC-2010 instrument (Shimadzu, Kyoto, Japan, model GC-MS TQ8040) was used for the analysis in collaboration with King Saud University. The chromatographic parameters were as follows: column, RTX-5MS (diphenyl dimethyl polysiloxane: $30.0 \mathrm{~m}$ $\times 0.25 \mathrm{~mm}$ ); injection, split injection; injection volume, $1 \mu \mathrm{L}$; split ratio: 50.0 . The initial temperature was $80^{\circ} \mathrm{C}$ with a hold time of $2 \mathrm{~min}$; after this, the temperature was raised to $315^{\circ} \mathrm{C}$ with a rate of $10^{\circ} \mathrm{C} / \mathrm{min}$ and held for $15 \mathrm{~min}$. Helium gas was used as a carrier, with a flow rate of $2 \mathrm{~mL} / \mathrm{min}$, and the total processing time was 40 to $50 \mathrm{~min}$. The obtained picks were analyzed by matching with the available NIST GC-MS database and the concentration (calculated using the peak area of the internal reference adonitol) was expressed as $\mu \mathrm{g} / \mathrm{g}$ fresh weight.

\subsection{Statistical Analysis and Data Visualization}

Metabolomics datasets were analyzed by multivariate analysis methods, including principal component analysis (PCA), partial least squares discriminant analysis (PLS-DA), and orthogonal projections to latent structures discriminant analysis (OPLS-DA) [79]. The Kyoto Encyclopedia of Genes and Genomes database was used to annotate metabolites and different heatmaps were constructed to represent the differential expression of metabolites under varying stress conditions.

\section{Results}

\subsection{Differential Accumulation of Metabolites under Different Stress Conditions}

Metabolites were extracted from both Suaeda plants grown under different abiotic stress conditions and analyzed by GC-MS. A total of 61 primary metabolites were detected in the leaves of both Suaeda species under different conditions (Table 1). These identified metabolites belong to different groups: 14 amino acids, 20 sugars, 11 sugar acids, 6 fatty acids, 9 different compounds, and 1 flavonoid (kaempferol). These metabolites were commonly observed and quantified in various abiotic stress conditions in both Suaeda species. Of the 14 amino acids, some are nutraceutical essential amino acids that are necessary ingredients for functional food and play a vital role in human health, including the proper functioning of numerous biosynthesis mechanisms. 
Table 1. Comprehensive metabolite profiling of Suaeda spp. under different integrated abiotic stress conditions.

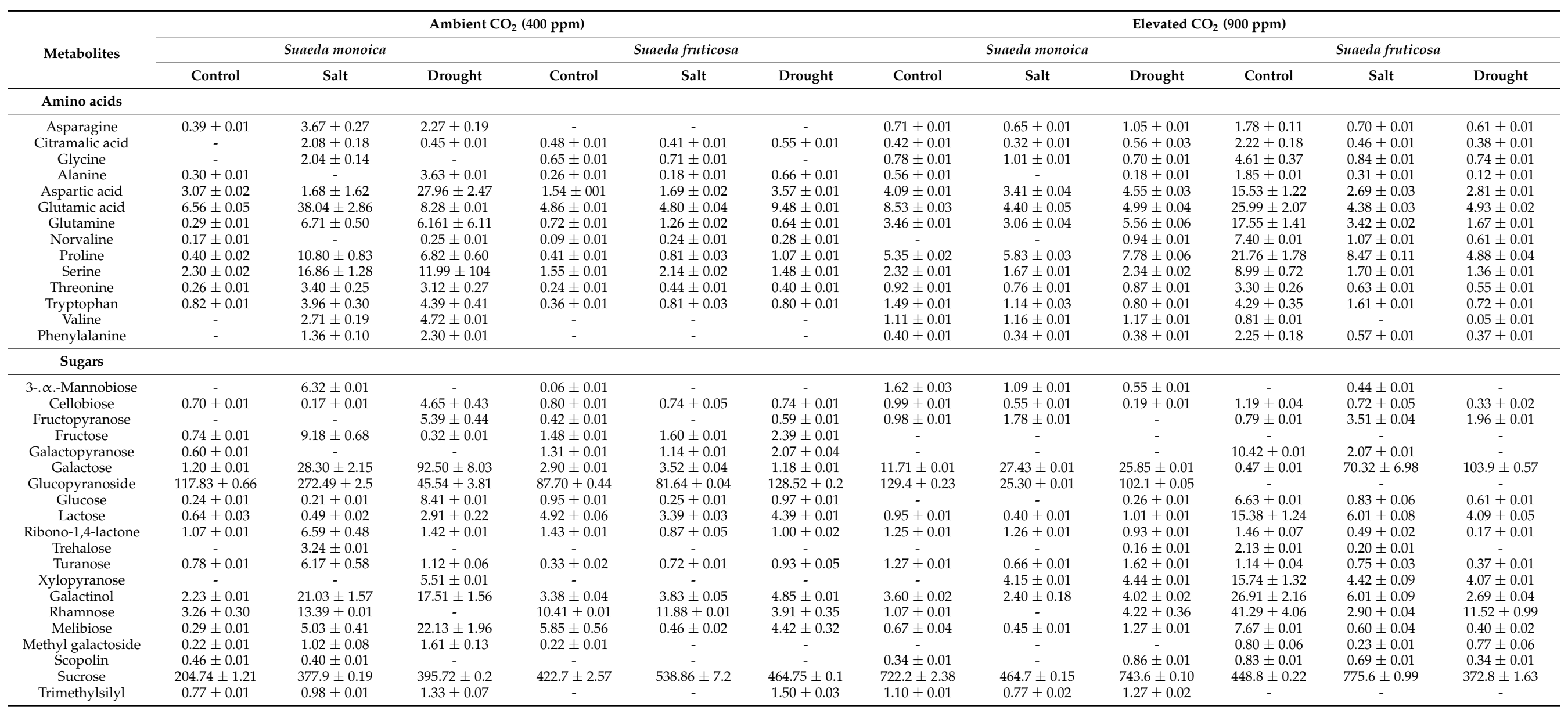


Table 1. Cont.

\begin{tabular}{|c|c|c|c|c|c|c|c|c|c|c|c|c|}
\hline \multirow{3}{*}{ Metabolites } & \multicolumn{6}{|c|}{ Ambient $\mathrm{CO}_{2}(400 \mathrm{ppm})$} & \multicolumn{6}{|c|}{ Elevated $\mathrm{CO}_{2}(900 \mathrm{ppm})$} \\
\hline & \multicolumn{3}{|c|}{ Suaeda monoica } & \multicolumn{3}{|c|}{ Suaeda fruticosa } & \multicolumn{3}{|c|}{ Suaeda monoica } & \multicolumn{3}{|c|}{ Suaeda fruticosa } \\
\hline & Control & Salt & Drought & Control & Salt & Drought & Control & Salt & Drought & Control & Salt & Drought \\
\hline \multicolumn{13}{|l|}{ Sugar acids } \\
\hline Mannitol & $0.36 \pm 0.02$ & & & & & & & $0.34 \pm 0.01$ & $0.45 \pm 0.01$ & $7.68 \pm 0.01$ & $0.57 \pm 0.01$ & $1.32 \pm 0.01$ \\
\hline Glyceric acid & $1.96 \pm 0.03$ & $13.52 \pm 1.02$ & $16.57 \pm 1.45$ & $1.73 \pm 0.01$ & $1.71 \pm 0.02$ & $1.48 \pm 0.01$ & $5.37 \pm 0.01$ & $2.19 \pm 0.01$ & $1.93 \pm 0.01$ & $6.28 \pm 0.50$ & $1.32 \pm 0.03$ & $1.23 \pm 0.01$ \\
\hline Threonic acid & $4.30 \pm 0.05$ & $5.63 \pm 0.01$ & $6.91 \pm 0.60$ & $1.75 \pm 0.01$ & $1.23 \pm 0.10$ & $3.11 \pm 0.28$ & $3.50 \pm 0.11$ & $1.35 \pm 0.06$ & $0.97 \pm 0.01$ & $7.63 \pm 0.60$ & $0.65 \pm 0.02$ & $1.80 \pm 0.04$ \\
\hline Ribonic acid & $0.94 \pm 0.01$ & $5.99 \pm 0.44$ & $6.74 \pm 0.59$ & $1.30 \pm 0.01$ & $1.44 \pm 0.01$ & $1.15 \pm 0.01$ & $1.38 \pm 0.01$ & $0.99 \pm 0.01$ & $7.62 \pm 0.64$ & $7.64 \pm 0.01$ & $1.37 \pm 0.02$ & $0.81 \pm 0.01$ \\
\hline Citric acid & $3.06 \pm 0.05$ & $46.95 \pm 3.40$ & $39.58 \pm 3.49$ & $9.21 \pm 0.01$ & $17.27 \pm 0.30$ & $12.33 \pm 0.15$ & $10.34 \pm 0.12$ & $6.95 \pm 0.11$ & $5.56 \pm 0.14$ & $24.09 \pm 1.96$ & $10.93 \pm 0.21$ & $4.30 \pm 0.08$ \\
\hline Glucuronic acid & $0.16 \pm 0.01$ & $1.32 \pm 0.05$ & $2.50 \pm 0.01$ & $0.22 \pm 0.01$ & $3.52 \pm 0.01$ & $2.34 \pm 0.01$ & $4.81 \pm 0.03$ & - & - & & - & - \\
\hline Galactaric acid & $8.92 \pm 0.14$ & $44.58 \pm 3.33$ & $6.78 \pm 0.17$ & $18.29 \pm 0.08$ & $16.08 \pm 0.12$ & $27.66 \pm 0.30$ & $7.76 \pm 0.05$ & $5.24 \pm 0.04$ & $9.29 \pm 0.22$ & $5.01 \pm 0.45$ & $2.21 \pm 0.21$ & $8.08 \pm 0.11$ \\
\hline Tartaric acid & $10.39 \pm 0.10$ & $40.53 \pm 3.06$ & $37.43 \pm 3.28$ & $9.67 \pm 0.06$ & $10.00 \pm 0.07$ & $12.99 \pm 0.05$ & $10.26 \pm 0.02$ & $6.18 \pm 0.07$ & $9.91 \pm 0.15$ & $39.20 \pm 3.15$ & $10.07 \pm 0.26$ & $6.81 \pm 0.06$ \\
\hline Oxalic acid & $0.24 \pm 0.01$ & - & $1.19 \pm 0.02$ & $0.11 \pm 0.01$ & $0.17 \pm 0.01$ & - & $0.37 \pm 0.01$ & $0.24 \pm 0.01$ & $0.29 \pm 0.01$ & $0.67 \pm 0.04$ & $0.14 \pm 0.01$ & $0.21 \pm 0.01$ \\
\hline \multicolumn{13}{|l|}{ Fatty acids } \\
\hline $\begin{array}{l}\text { 2-Aminobutanoic } \\
\text { acid }\end{array}$ & $0.60 \pm 0.01$ & $1.76 \pm 0.11$ & $2.95 \pm 0.25$ & $0.39 \pm 0.01$ & $0.10 \pm 0.01$ & $0.36 \pm 0.01$ & $0.39 \pm 0.01$ & $0.40 \pm 0.0$ & $1.30 \pm 0.01$ & $2.79 \pm 0.22$ & $0.57 \pm 0.01$ & $0.47 \pm 0.01$ \\
\hline Butanedioic acid & $0.74 \pm 0.01$ & $4.36 \pm 0.33$ & $4.20 \pm 0.34$ & $0.93 \pm 0.01$ & $0.73 \pm 0.01$ & $0.73 \pm 0.02$ & $1.51 \pm 0.01$ & $1.02 \pm 0.01$ & $1.67 \pm 0.01$ & $5.50 \pm 0.44$ & $0.71 \pm 0.01$ & $0.91 \pm 0.01$ \\
\hline Glucopyranose & - & $9.95 \pm 0.78$ & $21.15 \pm 1.78$ & $0.83 \pm 0.01$ & $1.98 \pm 0.05$ & - & $1.40 \pm 0.01$ & $2.38 \pm 0.04$ & $2.18 \pm 0.11$ & $10.29 \pm 0.92$ & $3.26 \pm 0.04$ & $2.62 \pm 0.01$ \\
\hline Malic acid & $18.12 \pm 0.19$ & $205.7 \pm 15.6$ & $301.8 \pm 26.3$ & $27.15 \pm 0.03$ & $26.48 \pm 0.06$ & $32.37 \pm 0.05$ & $77.16 \pm 0.21$ & $42.68 \pm 0.30$ & $29.26 \pm 0.29$ & $136.3 \pm 10.8$ & $24.85 \pm 0.43$ & $19.28 \pm 0.02$ \\
\hline Myo-Inositol & $0.76 \pm 0.01$ & $7.81 \pm 0.58$ & $7.81 \pm 0.64$ & $0.48 \pm 0.01$ & $1.10 \pm 0.01$ & $1.35 \pm 0.01$ & $1.35 \pm 0.01$ & $0.81 \pm 0.01$ & $1.11 \pm 0.01$ & $4.25 \pm 0.34$ & $0.99 \pm 0.02$ & $0.86 \pm 0.01$ \\
\hline $\begin{array}{c}\beta \text { - } \\
\text { Galactopyranoside }\end{array}$ & $0.63 \pm 0.02$ & $2.01 \pm 0.01$ & - & $1.10 \pm 0.01$ & $0.96 \pm 0.01$ & $0.78 \pm 0.01$ & $1.18 \pm 0.01$ & - & $0.85 \pm 0.01$ & $4.18 \pm 0.33$ & $2.67 \pm 0.02$ & $2.03 \pm 0.02$ \\
\hline \multicolumn{13}{|l|}{ Miscellaneous } \\
\hline \multicolumn{13}{|l|}{ 2-Butenedioic acid } \\
\hline $\begin{array}{l}\text { 3-Hydroxy-DL- } \\
\text { tyrosine }\end{array}$ & $0.47 \pm 0.01$ & $7.06 \pm 0.53$ & $25.32 \pm 2.21$ & $1.57 \pm 0.01$ & $1.54 \pm 0.04$ & $3.48 \pm 0.07$ & $3.92 \pm 0.03$ & $0.48 \pm 0.01$ & $1.59 \pm 0.02$ & $13.78 \pm 1.11$ & $2.30 \pm 0.02$ & $2.01 \pm 0.01$ \\
\hline Erythrono & $0.30 \pm 0.01$ & $2.09 \pm 0.18$ & $3.11 \pm 0.01$ & $0.20 \pm 0.01$ & $0.34 \pm 0.01$ & $0.21 \pm 0.01$ & $0.31 \pm 0.01$ & $0.36 \pm 0.01$ & $0.18 \pm 0.01$ & $0.97 \pm 0.07$ & $0.14 \pm 0.01$ & $0.22 \pm 0.01$ \\
\hline Ethanolamine & $0.08 \pm 0.01$ & $1.92 \pm 0.16$ & $3.14 \pm 0.01$ & $0.36 \pm 0.01$ & $0.53 \pm 0.01$ & $0.55 \pm 0.01$ & $0.54 \pm 0.01$ & $0.39 \pm 0.0$ & $0.96 \pm 0.02$ & $3.91 \pm 0.31$ & $0.58 \pm 0.01$ & $0.44 \pm 0.01$ \\
\hline Ferulic acid & $0.36 \pm 0.01$ & $2.39 \pm 0.19$ & & $0.34 \pm 0.01$ & $0.40 \pm 0.01$ & $0.55 \pm 0.02$ & $0.49 \pm 0.01$ & $0.29 \pm 0.01$ & $0.72 \pm 0.01$ & $2.90 \pm 0.24$ & $0.23 \pm 0.01$ & $0.18 \pm 0.01$ \\
\hline Melatonin & $36.72 \pm 0.75$ & $198.8 \pm 13.6$ & $527.2 \pm 45.7$ & $63.54 \pm 0.40$ & $71.22 \pm 1.27$ & $176.1 \pm 9.71$ & $125.3 \pm 0.01$ & $135.7 \pm 4.70$ & $159.7 \pm 0.45$ & $685.1 \pm 55.1$ & $231.8 \pm 0.19$ & $58.47 \pm 0.13$ \\
\hline Quininic acid & $0.24 \pm 0.01$ & $1.01 \pm 0.08$ & $2.44 \pm 0.01$ & $0.26 \pm 0.01$ & $0.38 \pm 0.01$ & $0.19 \pm 0.01$ & - & $0.16 \pm 0.01$ & $0.34 \pm 0.01$ & $1.10 \pm 0.09$ & $0.37 \pm 0.01$ & $0.22 \pm 0.01$ \\
\hline Silanol & $3.25 \pm 0.07$ & $15.67 \pm 1.18$ & $9.60 \pm 0.84$ & $1.58 \pm 0.01$ & $1.19 \pm 0.01$ & $2.46 \pm 0.01$ & $3.59 \pm 0.04$ & $0.41 \pm 0.01$ & $2.58 \pm 0.02$ & $13.00 \pm 1.02$ & $0.61 \pm 0.02$ & $1.17 \pm 0.01$ \\
\hline Uridine & $0.14 \pm 0.01$ & $1.82 \pm 0.14$ & $1.18 \pm 0.01$ & $0.39 \pm 0.01$ & $0.23 \pm 0.01$ & $0.17 \pm 0.01$ & & & & & & \\
\hline Flavonoid & & & & & & & & & & & & \\
\hline Kaempferol & - & - & - & $0.20 \pm 0.01$ & $0.25 \pm 0.01$ & $0.36 \pm 0.01$ & $0.28 \pm 0.01$ & $2.91 \pm 0.01$ & $0.60 \pm 0.01$ & $2.33 \pm 0.20$ & $0.27 \pm 0.01$ & $0.13 \pm 0.01$ \\
\hline
\end{tabular}


Amino acids, including proline, serine, threonine, aspartic acid, glutamic acid, glutamine, and tryptophan, accumulate differentially in both Suaeda species under salt and drought stress under ambient $\mathrm{CO}_{2}$ conditions. In contrast, under elevated $\mathrm{CO}_{2}$ conditions, their concentrations decreased under salt or drought stress compared to the corresponding control conditions, but the overall level was higher than ambient $\mathrm{CO}_{2}$ conditions. Asparagine, valine, and phenylalanine were not detected in S. fruticosa under ambient $\mathrm{CO}_{2}$ (control and stress) conditions. However, these amino acids were detected under elevated $\mathrm{CO}_{2}$ (control and stress; salt or drought) conditions in S. monoica. Some photorespiratory essential amino acids, such as serine and glycine, were also detected in both Suaeda species. We found that the serine concentration was higher in S. monoica compared to S. fruticosa under different stress conditions. Interestingly, their concentrations decreased under elevated $\mathrm{CO}_{2}$ stress conditions compared to their respective control conditions.

Sugars are also major metabolites contributing to stress tolerance. About 20 different sugars were detected under varying stress conditions. Sugars are an essential energy source for any biosynthesis process, including lipids and proteins, and act as a vitamin $\mathrm{C}$ precursor. Furthermore, sugars, also known as osmoprotectants, are commonly accumulated under stress conditions in plants. One of the sugars (i.e., fructose) was detected in both Suaeda species under ambient $\mathrm{CO}_{2}$ (control and stress) conditions but not under elevated $\mathrm{CO}_{2}$ conditions. Some important sugars, including galactose, turanose, rhamnose, melibiose, cellobiose, sucrose, lactose, galactinol, lactose, galactinol, and ribono-1,4-lactone, were detected in both Suaeda species. High accumulation was determined under stress conditions, but their contents were not significantly affected under elevated $\mathrm{CO}_{2}$ stress conditions.

Four sugar acids, including ribonic acid, galacturonic acid, glyceric acid, and threonic acid, were detected in both Suaeda species under salt and drought stress at ambient or elevated $\mathrm{CO}_{2}$ stress conditions. These sugar acids accumulated under ambient $\mathrm{CO}_{2}$ stress conditions compared to control, whereas their content decreased under elevated $\mathrm{CO}_{2}$ stress conditions. Likewise, other sugar acids and metabolites of the TCA cycle, such as citric acid, tartaric acid, glucuronic acid, oxalic acid, psicose, and galactaric acid, showed a similar trend. Aside from these metabolites, nine miscellaneous metabolites, including 2-butanedioic acid, 3-hydroxy-DL-tyrosine, erythrono, ethanolamine, ferulic acid, melatonin, quininic acid, silanol, and uridine, were detected in both species under control and stress conditions (Table 1). Two of the most important bioactive compounds that act as antioxidants and antidiabetics (melatonin and quininic acid) accumulated in ambient $\mathrm{CO}_{2}$ stress conditions, especially under drought stress in both Suaeda plants. In contrast, their accumulation decreased under elevated $\mathrm{CO}_{2}$ stress conditions compared to control in S. fruticosa.

\subsection{Multivariate Statistical Analysis}

The integrated PCA showed the possible correlation of plant responses to different stress conditions. A bi-plot deduced from the PCA separated treatments into the first two components with an overall variability of $84.91 \%$ (PC1: 75\% and PC2: 9.91\%). The bi-plot clustered metabolites according to the effects of stress treatments. The most significant effects were observed with elevated $\mathrm{CO}_{2}$ among all other stress combinations in both Suaeda species (Figure 1). Similarly, a score plot was generated based on PLS-DA. The score plot represented a clustering of different metabolites detected in plants treated with different stress conditions (Figure 2). The score plot revealed that drought and salt stress significantly affect the metabolism of $S$. monoica compared to other stress conditions, whereas in $S$. fruticosa, elevated $\mathrm{CO}_{2}$ had a significant effect on plants compared to other stresses. OPLS-DA is a regression model used to calculate a correlation between the multivariate data and a response variable in the metabolomics. OPLS-DA of S. monoica and $S$. fruticosa showed a correlation between two plants treated with different stress conditions. The $R^{2}$ and $Q^{2}$ values revealed that the model is more stable, reliable, and excellent for the study. A hierarchical cluster analysis was performed and heatmaps generated based on Spearman's rank correlation coefficients showed a correlation among pairs of plants 
treated with varying stress conditions and pairs of extracted metabolites. Spearman's rank correlation analysis is commonly used to study a relationship between two variables. In this correlation study, we determined whether two variables covary (vary together with another variable). A cumulative heatmap showing a correlation between metabolites and plants grown under different stress conditions (Figure 3) revealed differential expression or accumulation of metabolites under stress conditions.

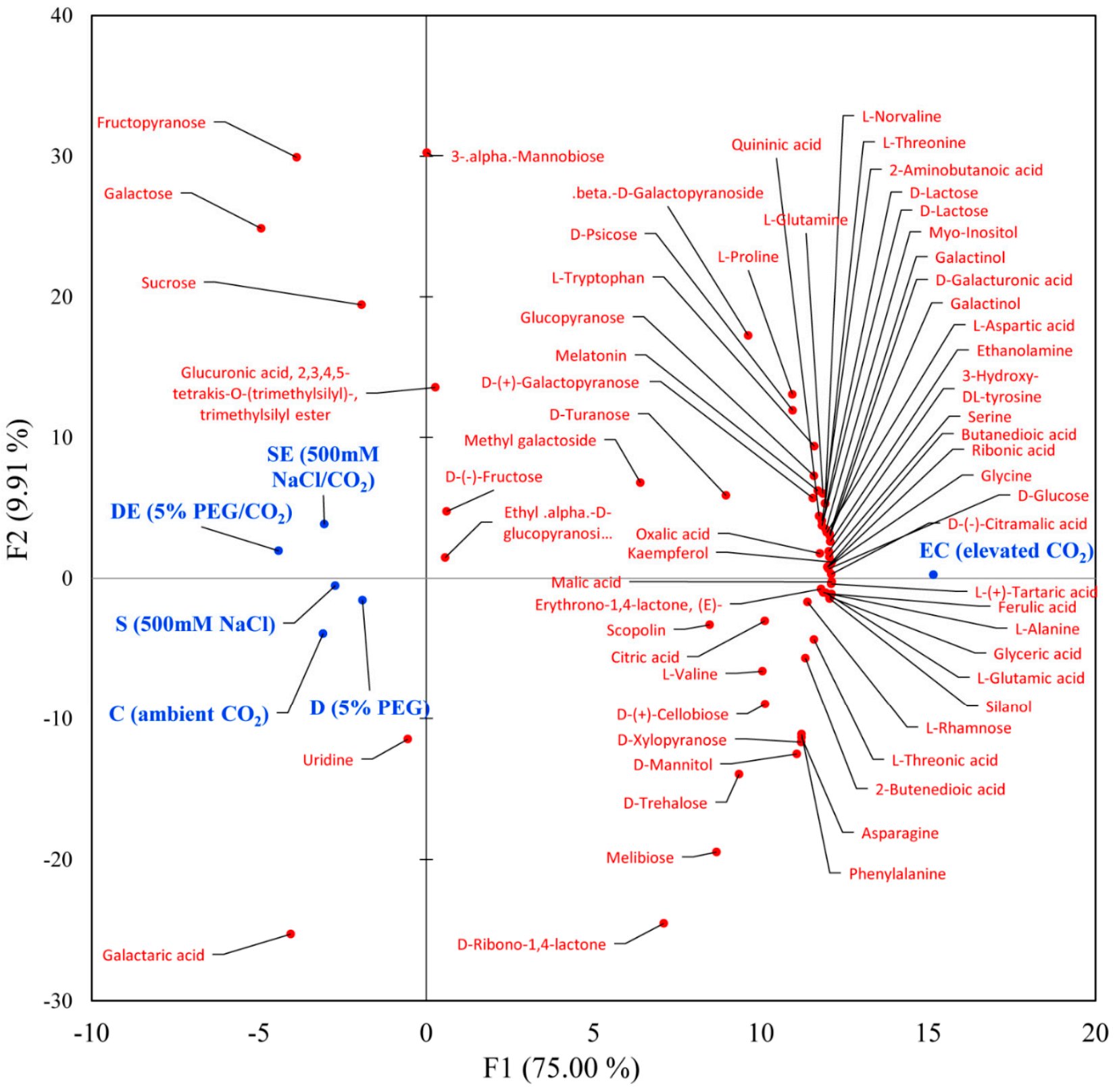

Figure 1. Cont. 
B

Biplot (axes F1 and F2: $84.91 \%$ )



Figure 1. An integrated bi-plot-based principal component analysis. Bi-plot-correlated metabolites expressed in response to stress conditions in (A) S. monoica and (B) S. fruticosa. C: plants grown under ambient conditions; EC: plants under elevated $\mathrm{CO}_{2} \mathrm{Conditions}$ S: salt $(500 \mathrm{mM} \mathrm{NaCl})$ stress under ambient $\mathrm{CO}_{2}$ conditions; $\mathrm{SE}$ : salt $(500 \mathrm{mM} \mathrm{NaCl})$ stress under elevated $\mathrm{CO}_{2} ; \mathrm{D}$ : drought or osmotic (5\% PEG) stress under ambient $\mathrm{CO}_{2}$ conditions; DE: drought or osmotic (5\% PEG) stress under elevated $\mathrm{CO}_{2}$ conditions. 


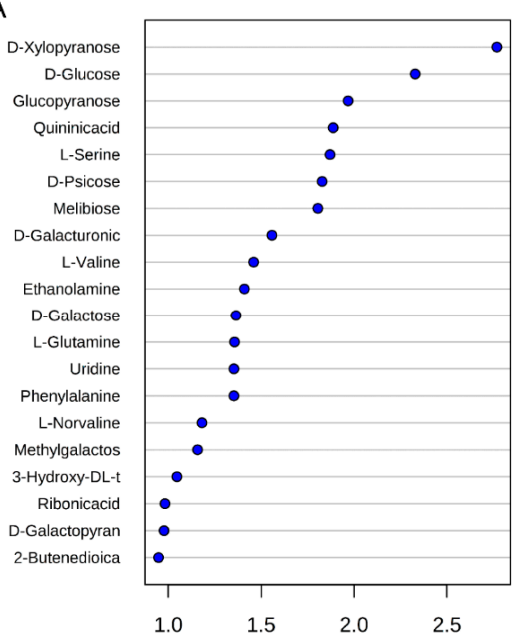

B

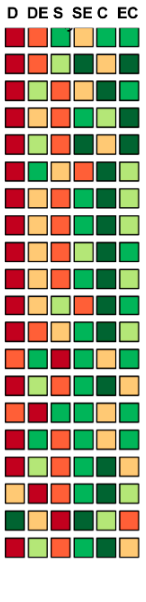

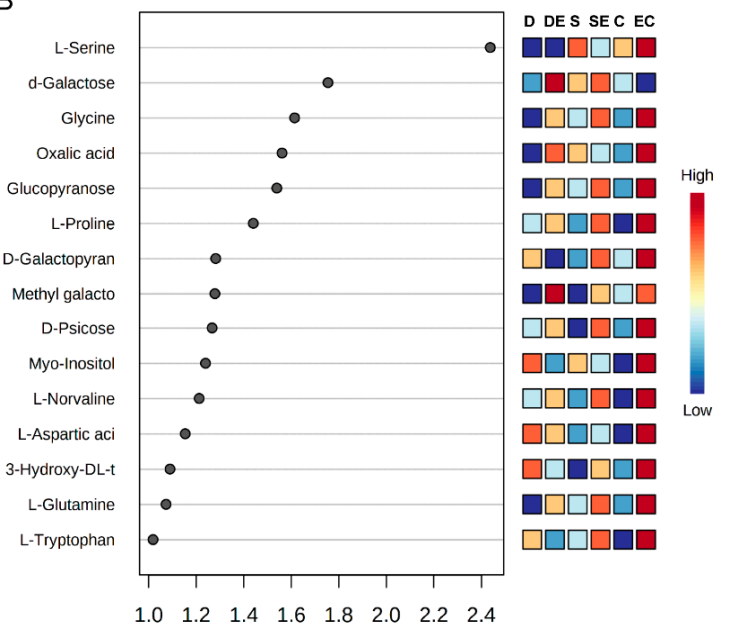

Figure 2. Partial least squares discriminant analysis (PLS-DA) of plants treated with different stress conditions. The PLS-DA represents the important metabolites and their relative accumulation in (A) S. monoica and (B) S. fruticosa in response to different stress conditions based on the variable importance in projection score. C: plants grown under ambient conditions; EC: plants under elevated $\mathrm{CO}_{2}$ conditions; $\mathrm{S}$ : salt $(500 \mathrm{mM} \mathrm{NaCl})$ stress under ambient $\mathrm{CO}_{2}$ conditions; $\mathrm{SE}$ : salt (500 mM $\mathrm{NaCl}$ ) stress under elevated $\mathrm{CO}_{2}$; D: drought or osmotic (5\% PEG) stress under ambient $\mathrm{CO}_{2}$ conditions; DE: drought or osmotic (5\% PEG) stress under elevated $\mathrm{CO}_{2}$ conditions.
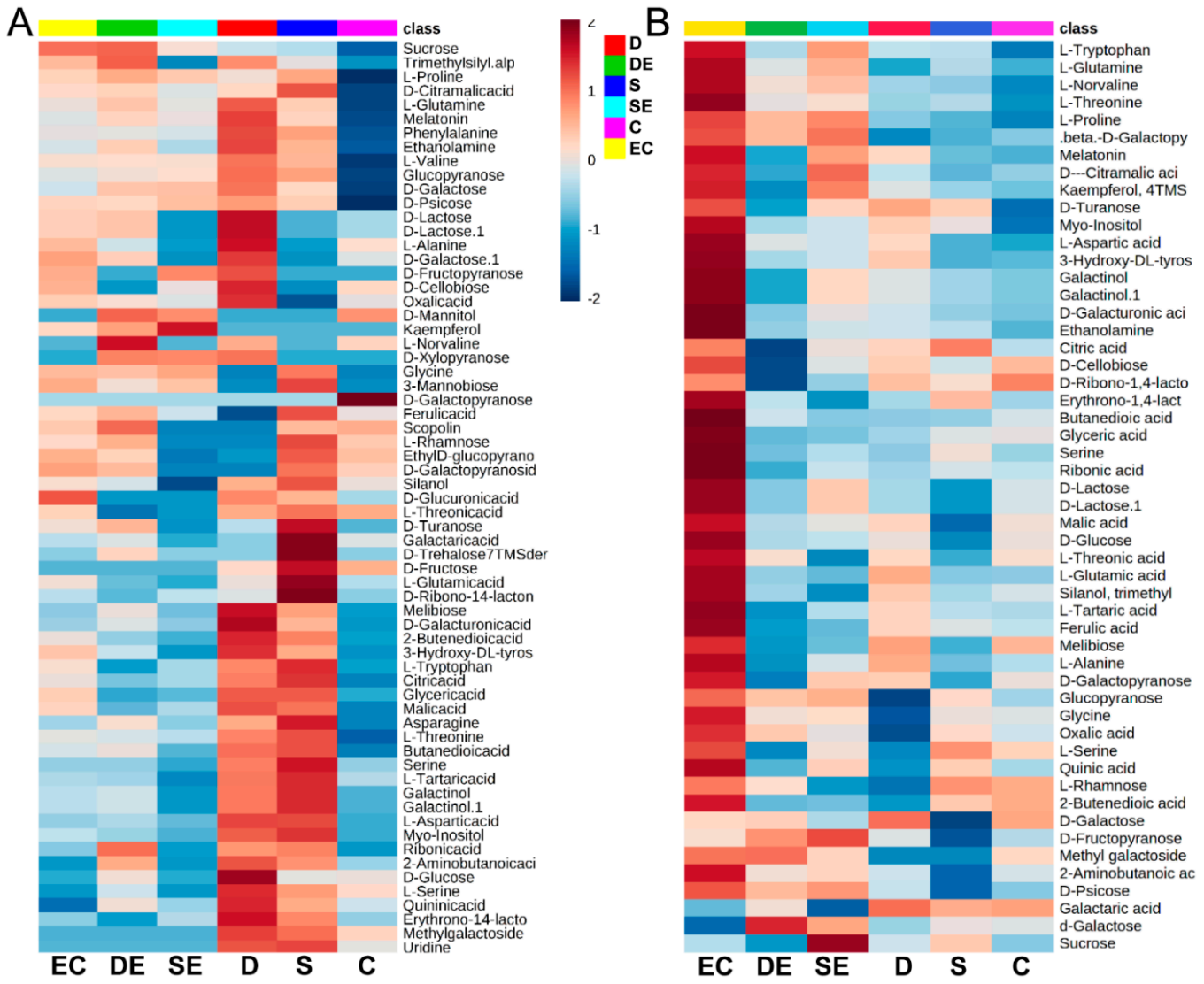

Figure 3. Heatmap representing the correlations between metabolites and plants treated with different stress conditions. The heatmap represents the correlation between metabolites and (A) S. monoica and (B) S. fruticosa grown under varying stress conditions. C: plants grown under ambient conditions; EC: plants under elevated $\mathrm{CO}_{2}$ conditions; $\mathrm{S}$ : salt (500 mM $\mathrm{NaCl})$ stress under ambient $\mathrm{CO}_{2}$ conditions; SE: salt $(500 \mathrm{mM} \mathrm{NaCl})$ stress under elevated $\mathrm{CO}_{2} ; \mathrm{D}$ : drought or osmotic $(5 \%$ PEG) stress under ambient $\mathrm{CO}_{2}$ conditions; DE: drought or osmotic ( $5 \%$ PEG) stress under elevated $\mathrm{CO}_{2}$ conditions. 
In ambient $\mathrm{CO}_{2}$ conditions, intermediates of the Krebs cycle, including malic acid, accumulate in leaves of $S$. monoica under salt and drought stress conditions, whereas in $S$. fruticosa, no significant difference was found between control and stress conditions. In contrast, in elevated $\mathrm{CO}_{2}$ conditions, the malic acid concentration was decreased under stress conditions compared to control conditions in both Suaeda species. This study demonstrated that the key metabolites involved in plant metabolism were differentially accumulated or expressed under varying stress conditions in Suaeda plants (Figure 4). These metabolites are involved in basic metabolic pathways.

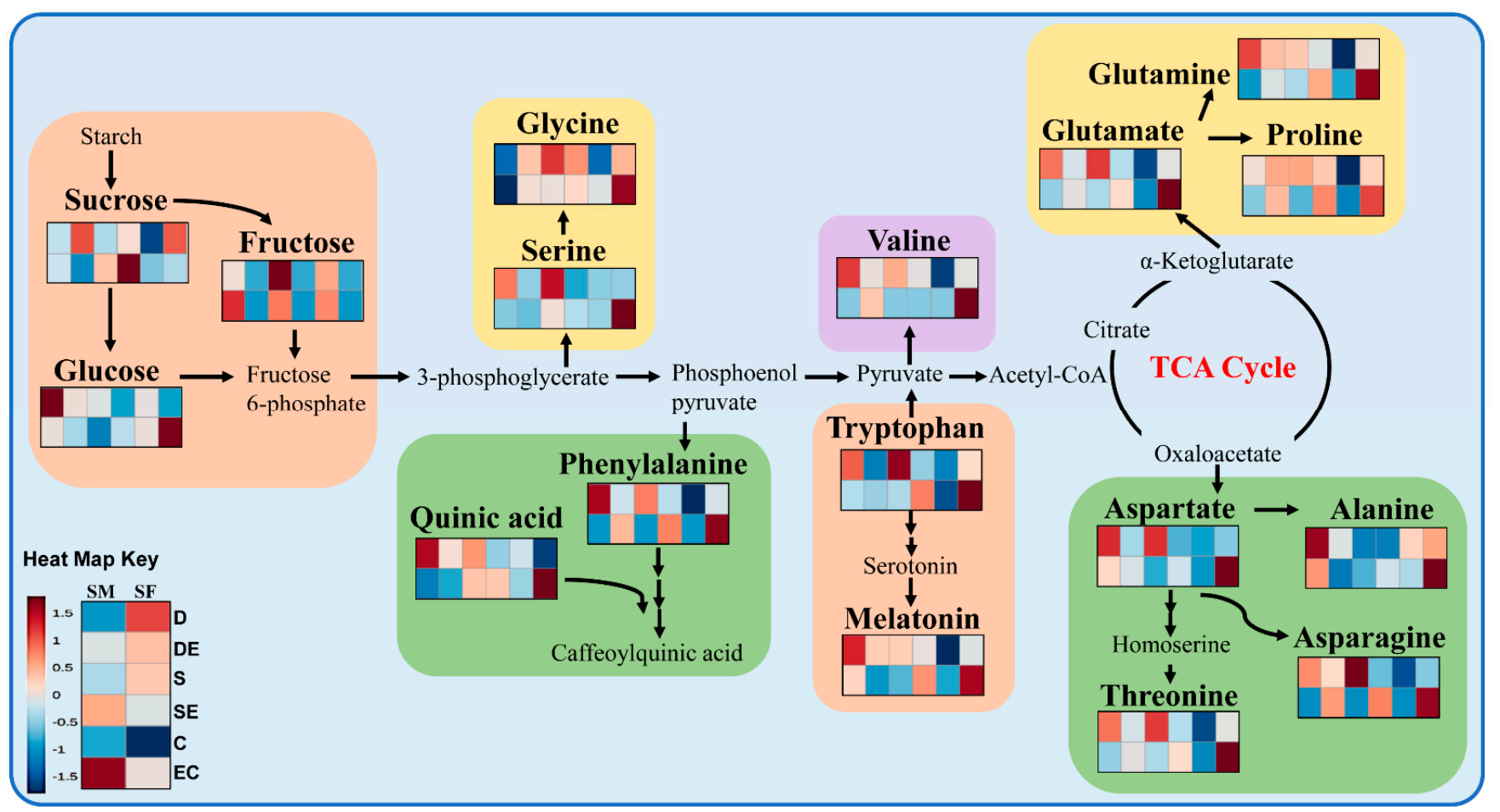

Figure 4. Schematic presentation of the pathways for certain important metabolites. Metabolites were differentially accumulated or expressed under varying stress conditions. The relative quantification of metabolites was performed by GC-MS. Samples were analyzed and the average metabolite abundance was used to calculate the differences of the changes (represented by different colors) relative to control. C: plants grown under ambient conditions; EC: plants under elevated $\mathrm{CO}_{2}$ conditions; S: salt $(500 \mathrm{mM} \mathrm{NaCl})$ stress under ambient $\mathrm{CO}_{2}$ conditions; SE: salt $(500 \mathrm{mM} \mathrm{NaCl})$ stress under elevated $\mathrm{CO}_{2}$; D: drought/osmotic (5\% PEG) stress under ambient $\mathrm{CO}_{2}$ conditions; DE: drought/osmotic (5\% PEG) stress under elevated $\mathrm{CO}_{2}$ conditions.

\section{Discussion}

Plants have different strategies to deal with stresses, including adjusting their metabolic status [14]. Plants under individual or a combination of salt, drought, and elevated $\mathrm{CO}_{2}$ stress conditions are coordinated with the activation of different molecular and physiological responses. However, these changes lead to alterations in plant metabolism that mitigate the damaging effects of stress combinations. The acclimatization of plant species to any stress seems to be diverse from a metabolic point of view. Different stresses induce differential gene expression and modifications in various metabolites, including amino acids, organic acid, and carbohydrates, which play essential roles in carbon assimilation, photorespiration, signal regulation, and protein synthesis [80,81]. Many studies have demonstrated that elevated $\mathrm{CO}_{2}$ could promote plant metabolism and ameliorate the detrimental effects of abiotic stress on plant species varieties. In $\mathrm{C}_{4}$ plants, elevated $\mathrm{CO}_{2}$ decreases ROS production and oxidative damage; however, this means that other non-stomatal processes and reduced photorespiration contribute to stress mitigation [82]. 
Omics methodologies widely used to study plant responses provide multiple metabolic progressions under elevated $\mathrm{CO}_{2}$ stress conditions $[10,53,83]$. Therefore, we speculated that although these two halophytes belong to the same genus (but different species), their strategies to deal with different stresses may be quite different.

Metabolite profiling is an effective and quantitative process used to elucidate the stress tolerance mechanism. Plants under different stress combinations (salt, drought, and elevated $\mathrm{CO}_{2}$ ) have revealed a wide variety of metabolites that precisely change during stress, such as osmoprotectants, amino acids, fatty acids, carbohydrates, sugar acids, and some intermediates of the Krebs cycle $[84,85]$. The accumulation of osmoprotectants, such as compatible solutes (proline and sucrose), is a typical plant response involved in several mechanisms, such as maintaining the membrane's protein stability and cell osmotic pressure (adjustment) [86]. Proline accumulated under salt and drought stress under ambient $\mathrm{CO}_{2}$ conditions in both Suaeda species. In contrast, under elevated $\mathrm{CO}_{2}$ (control and stress) conditions, the proline concentration significantly increased compared to ambient $\mathrm{CO}_{2}$ control and stress conditions. Likewise, sucrose accumulation was considerably higher among other metabolites during stress conditions. Sucrose accumulated under salt and drought stress conditions in both Suaeda species in ambient $\mathrm{CO}_{2}$ conditions as compared to control (Table 1). Similar results were also observed in Arabidopsis thaliana under drought and heat stress conditions, where proline accumulated during drought stress, whereas sucrose accumulated during a combination of stresses to protect the mitochondrial and cellular components during stress [87]. In contrast, purslane plants accumulated proline under individual, heat, and drought stress conditions but not in combination [88]. In ambient $\mathrm{CO}_{2}$ conditions under heat stress, different metabolites were significantly accumulated, such as succinic acid, aspartic acid, some essential amino acid, malic acid, and some sugars in Poa pratensis (Kentucky bluegrass) [89].

An accumulation of other metabolites and their concentrations was also observed in Suaeda species exposed to salt and drought stress with a combination of ambient and elevated $\mathrm{CO}_{2}$ conditions (Figures 1-3). In this study, Suaeda species can cope with the adverse effects of abiotic stress conditions by accumulating different sugars, amino acids, fatty acids, and other metabolic compounds. Furthermore, different amino acids, including asparagine, citramalic acid, glycine, alanine, glutamic acid, aspartic acid, glutamine, norvaline, proline, serine, threonine, valine, tryptophan, and phenylalanine, showed increased accumulation under ambient $\mathrm{CO}_{2}$ stress conditions compared to controls. In S. monoica, asparagine content increased under salt and drought stress, supporting the observation that accumulation is up to a substantial extent under stress conditions [90], implying that certain amino acids have different sensitivity toward stress responses in different plants under different stress conditions.

Similarly, A. thaliana and purslane plants accumulate different types of amino acids, including tyrosine, tryptophan, glutamine, valine, and ornithine, to play an essential role in the osmotic adjustment of cellular components aimed at maintaining leaf turgor under stress treatment $[83,84]$. Aromatic amino acids, such as tryptophan, involved in the downstream regulation of the shikimic acid pathway increased in both Suaeda species under salt and drought stress in ambient $\mathrm{CO}_{2}$ conditions. Furthermore, aromatic amino acids were decreased in both Suaeda species under salt and drought stress in elevated $\mathrm{CO}_{2}$ conditions as compared to control plants (Table 1). Accumulation of important amino acids under stress could be correlated with protein synthesis to protect and initiate fast recovery after stress in plant metabolism and osmotic adjustments [91]. This observation indicated that salt and drought stress rigorously affected $\mathrm{C}_{4}$ Suaeda physiological constraints, and that these detrimental effects were alleviated by elevated $\mathrm{CO}_{2}$ when combined with salt and drought stress.

In addition to amino acids, an increase in carbohydrates within a cell may be another strategy used for osmotic adjustment under stress conditions. Certain soluble sugars, including fructose, glucose, and sucrose, increased in Thellungiella and Arabidopsis [92]. The sucrose content in the xero-halophyte species, Atriplex halimus, increased significantly under 
salt stress conditions [93]. In this study, different sugar molecules accumulated in the leaves of both Suaeda species, however the accumulation was found to be insignificant, demonstrating the efficient protection of membranes and photosystem II from photo-oxidation damages. Koussevitzky et al. [94] reported that during a combination of high temperature and drought stress, accumulated malic enzyme in A. thaliana was correlated with its increased activity and a decline in malate and oxaloacetate concentrations, whereas under elevated $\mathrm{CO}_{2}$ conditions, a $\mathrm{C}_{3}$ turf grass species (Festuca arundinacea) showed improved abiotic stress tolerance under a combination of drought and heat stress by improving plant water use, photosynthesis efficiency, cellular membrane stability, and reduced rate of photorespiration [95]. Hence, it was considered that the metabolic alteration associated with the mitigation of abiotic stress damage by elevated $\mathrm{CO}_{2}$ would offer further insights into the collaborative effects of salt stress, drought stress, and enhanced environmental $\mathrm{CO}_{2}$ concentrations in plant species.

Thus, different bioactive compounds, such as quininic acid, kaempferol, and melatonin, were present in both Suaeda species in precise concentrations. Melatonin is a pleiotropic metabolic compound that not only plays a role in antioxidant activity but also induces the regulation of gene expression in various physiological progressions, including plant growth [96], germination, rooting [97], photosynthesis [98], and osmoregulation [99], and protects against different abiotic and biotic stresses [100-102]. Recently, the melatonin receptor was first identified and characterized in Arabidopsis [103]. Interestingly, different studies have indicated that melatonin might be considered as an emerging phytohormone, and its multiple functions also include being a vital redox homeostasis regulator in plant systems [104,105]. In this study, the melatonin content was higher in stress conditions in both Suaeda plants under ambient $\mathrm{CO}_{2}$ conditions but decreased under elevated $\mathrm{CO}_{2}$ stress conditions. Previous research suggested that kaempferol and quininic acid possess potent antioxidant and antidiabetic properties [106-108]. Kaempferol is a natural flavonoid that shows antioxidant, anticancer, and anti-inflammatory therapeutic properties and is present in different plant species [78,109].

Similarly, the ethanolic extract from Calotropis procera leaves was analyzed using ultrahigh performance liquid chromatography quadrupole time-of-flight mass spectrometry (UHPLC-QTOF-MS/MS). The extract also showed higher rates of antidiabetic and antioxidant metabolites, such as quininic acid, kaempferol, and p-hydroxybenzoic acid [108]. Kaempferol identified from S. maritima leaf extracts showed cytotoxic activity against human tumor cell lines [110]. Different types of metabolites accumulate in different species to provide osmotic protection under varying stress conditions. Differential synthesis and accumulation of metabolites are associated with enhanced stress tolerance [111], and may be result of the various pathways initiated in the different species in response to varying stresses.

This study addressed the variability of the metabolites in halophytes using metabolomics and analyzed their effects on stress tolerance, and also confirms that Suaeda is a valuable source of bioactive compounds with significantly potent antioxidant effects. Overall, this study suggests that differential accumulation of various metabolites of $\mathrm{C}_{4}$ Suaeda in response to different stress conditions, such as salt, drought, and elevated $\mathrm{CO}_{2}$ stress conditions, provides insights into stress tolerance in $\mathrm{C}_{4}$ plant species in relation to climate change. This work provides new perspectives on the important secondary metabolite pathway involved in stress tolerance between Suaeda species. Consequently, a detailed study of the tolerance mechanism of wetland plants is still needed.

Author Contributions: Conceptualization and design, A.M.; experimentation, S.Y.; data acquisition, S.Y.; analysis and interpretation, S.Y., M.A.M., H.O.E., K.M.E., M.A.A. and A.M.; software, S.Y., M.A.M., H.O.E., K.M.E., M.A.A. and A.M.; drafting of the article, S.Y. and A.M.; review and editing, A.M., K.M.E., M.A.A. and H.O.E.; funding acquisition, A.M., K.M.E., M.A.A. and H.O.E. All authors have read and agreed to the published version of the manuscript. 
Funding: The authors extend their appreciation to the Deanship of Scientific Research at King Saud University for funding this work through research group no. (RG-1436-020).

Institutional Review Board Statement: Not applicable.

Informed Consent Statement: Not applicable.

Data Availability Statement: The data presented in this study are available on request from the corresponding author.

Acknowledgments: The authors extend their appreciation to the Deanship of Scientific Research at King Saud University for funding this work through research group no. (RG-1436-020). The CSIR-Young Scientist (YSP-02/2016-17) project is thankfully acknowledged. CSIR-CSMCRI Communication No. is $192 / 2020$.

Conflicts of Interest: The authors declare no conflict of interest.

\section{References}

1. Bray, E.A.; Bailey-Serres, J.; Weretilnyk, E. Responses to abiotic stresses. In Biochemistry and Molecular Biology of Plants; Buchanan, B.B., Gruissem, W., Jones, R.L., Eds.; American Society of Plant Physiologists: Rockville, MD, USA, 2000; pp. 1158-1203.

2. Carmo-Silva, A.E.; Gore, M.A.; Andrade-Sanchez, P.; French, A.N.; Hunsaker, D.J.; Salvucci, M.E. Decreased $\mathrm{CO}_{2}$ availability and inactivation of Rubisco limit photosynthesis in cotton plants under heat and drought stress in the field. Environ. Exp. Bot. 2012, 83, 1-11. [CrossRef]

3. Awasthi, R.; Kaushal, N.; Vadez, V.; Turner, N.C.; Berger, J.; Siddique, K.H.M.; Nayyar, H. Individual and combined effects of transient drought and heat stress on carbon assimilation and seedfilling in chickpea. Funct. Plant Biol. 2014, 41, $1148-1167$. [CrossRef]

4. Leakey, A.D.B.; Uribelarrea, M.; Ainsworth, E.A.; Naidu, S.L.; Rogers, A.; Ort, D.R.; Long, S.P. Photosynthesis, productivity, and yield of maize are not affected by open-air elevation of $\mathrm{CO}_{2}$ concentration in the absence of drought. Plant Physiol. 2006, 140, 779-790. [CrossRef]

5. Qiao, Y.Z.; Zhang, H.Z.; Dong, B.D.; Shi, C.H.; Li, Y.X.; Zhai, H.M.; Liu, M.Y. Effects of elevated $\mathrm{CO}_{2}$ concentration on growth and water use efficiency of winter wheat under two soil water regimes. Agric. Water Manag. 2010, 97, 1742-1748. [CrossRef]

6. Allen, L.H.; Kakani, V.G.; Vu, J.C.V.; Boote, K.J. Elevated $\mathrm{CO}_{2}$ increases water use efficiency by sustaining photosynthesis of water-limited maize and sorghum. J. Plant Physiol. 2011, 168, 1909-1918. [CrossRef] [PubMed]

7. Zinta, G.; Abdelgawad, H.; Domagalska, M.A.; Vergauwen, L.; Knapen, D.; Nijs, I.; Janssens, I.A.; Beemster, G.T.S.; Asard, H. Physiological, biochemical, and genome-wide transcriptional analysis reveals that elevated $\mathrm{CO}_{2}$ mitigates the impact of combined heat wave and drought stress in Arabidopsis thaliana at multiple organizational levels. Glob. Chang. Biol. 2014, 20, 3670-3685. [CrossRef] [PubMed]

8. Long, S.P.; Ainsworth, E.A.; Rogers, A.; Ort, D.R. Rising atmospheric carbon dioxide: Plants FACE the future. Ann. Rev. Plant Biol. 2004, 55, 591-628. [CrossRef] [PubMed]

9. Ainsworth, E.A.; Long, S.P. 30 years of free-air carbon dioxide enrichment (FACE): What have we learned about future crop productivity and its potential for adaptation? Glob. Chang. Biol. 2021, 27, 27-49. [CrossRef] [PubMed]

10. AbdElgawad, H.; Zinta, G.; Beemster, G.T.; Janssens, I.A.; Asard, H. Future climate $\mathrm{CO}_{2}$ levels mitigate stress impact on plants: Increased defense or decreased challenge? Front. Plant Sci. 2016, 7, 556. [CrossRef]

11. Ghannoum, O.; Conroy, J.P.; Driscoll, S.P.; Paul, M.J.; Foyer, C.H.; Lawlor, D.W. Non-stomatal limitations are responsible for drought-induced photosynthetic inhibition in four $\mathrm{C}_{4}$ grasses. New Phytol. 2003, 159, 835-844. [CrossRef]

12. Liu, B.B.; Li, M.; Li, Q.M.; Cui, Q.Q.; Zhang, W.D.; Ai, X.Z.; Bi, H.G. Combined effects of elevated $\mathrm{CO}_{2}$ concentration and drought stress on photosynthetic performance and leaf structure of cucumber (Cucumis sativus L.) seedlings. Photosynthetica 2018, 56, 942-952. [CrossRef]

13. FAO. The State of Food Insecurity in the World 2015. Meeting the 2015 International Hunger Targets: Taking Stock of Uneven Progress; Food and Agriculture Organization Publications: Rome, Italy, 2016.

14. Mishra, A.; Tanna, B. Halophytes: Potential resources for salt stress tolerance genes and promoters. Front. Plant Sci. 2017, 8, 829. [CrossRef] [PubMed]

15. Kollist, H.; Zandalinas, S.I.; Sengupta, S.; Nuhkat, M.; Kangasjärvi, J.; Mittler, R. Rapid responses to abiotic stress: Priming the landscape for the signal transduction network. Trends Plant Sci. 2019, 24, 25-37. [CrossRef] [PubMed]

16. Zinta, G.; Abdelgawad, H.; Peshev, D.; Weedon, J.T.; Van Den Ende, W.; Nijs, I. Dynamics of metabolic responses to periods of combined heat and drought in Arabidopsis thaliana under ambient and elevated atmospheric $\mathrm{CO}_{2}$. J. Exp. Bot. 2018, 69, 2159-2170. [CrossRef] [PubMed]

17. Flowers, T.J.; Colmer, T.D. Salinity tolerance in halophytes. New Phytol. 2018, 179, 945-963. [CrossRef] [PubMed]

18. Yadav, S.; Mishra, A. Introgression of $C_{4}$ Pathway Gene (s) in $C_{3}$ Plants to Improve Photosynthetic Carbon Assimilation for Crop Improvement: A Biotechnological Approach. In Photosynthesis, Productivity and Environmental Stress; Ahmad, P., Ahanger, M.A., Alyemeni, M.N., Alam, P., Eds.; John Wiley: Blackwell, OK, USA, 2019; pp. 267-281. [CrossRef] 
19. Yadav, S.; Mishra, A. Ectopic expression of $\mathrm{C}_{4}$ photosynthetic pathway genes improves carbon assimilation and alleviate stress tolerance for future climate change. Physiol. Mol. Biol. Plants 2020, 26, 195-209. [CrossRef]

20. Benjamin, J.J.; Lucini, L.; Jothiramshekar, S.; Parida, A. Metabolomic insights into the mechanisms underlying tolerance to salinity in different halophytes. Plant Physiol. Biochem. 2019, 135, 528-545. [CrossRef]

21. Jha, B.; Singh, N.P.; Mishra, A. Proteome profiling of seed storage proteins reveals the nutritional potential of Salicornia brachiata Roxb., an extreme halophyte. J. Agric. Food Chem. 2012, 60, 4320-4326. [CrossRef]

22. Mishra, A.; Joshi, M.; Jha, B. Oligosaccharide mass profiling of nutritionally important Salicornia brachiata, an extreme halophyte. Carbohydr. Polym. 2013, 92, 1942-1945. [CrossRef]

23. Mishra, A.; Patel, M.K.; Jha, B. Non-targeted metabolomics and scavenging activity of reactive oxygen species reveal the potential of Salicornia brachiata as a functional food. J. Funct. Foods 2015, 13, 21-31. [CrossRef]

24. Patel, M.K.; Pandey, S.; Brahmbhatt, H.R.; Mishra, A.; Jha, B. Lipid content and fatty acid profile of selected halophytic plants reveal a promising source of renewable energy. Biomass Bioenergy 2019, 124, 25-32. [CrossRef]

25. Jha, B.; Sharma, A.; Mishra, A. Expression of SbGSTU (tau class glutathione S-transferase) gene isolated from Salicornia brachiata in tobacco for salt tolerance. Mol. Biol. Rep. 2011, 38, 4823-4832. [CrossRef] [PubMed]

26. Chaturvedi, A.K.; Mishra, A.; Tiwari, V.; Jha, B. Cloning and transcript analysis of type 2 metallothionein gene (SbMT-2) from extreme halophyte Salicornia brachiata and its heterologous expression in E. coli. Gene 2012, 499, 280-287. [CrossRef] [PubMed]

27. Chaturvedi, A.K.; Patel, M.K.; Mishra, A.; Tiwari, V.; Jha, B. The SbMT-2 gene from a halophyte confers abiotic stress tolerance and modulates ROS scavenging in transgenic tobacco. PLoS ONE 2014, 9, e111379. [CrossRef] [PubMed]

28. Jha, B.; Mishra, A.; Jha, A.; Joshi, M. Developing transgenic Jatropha using the SbNHX1 gene from an extreme halophyte for cultivation in saline wasteland. PLoS ONE 2013, 8, e71136. [CrossRef]

29. Singh, N.; Mishra, A.; Jha, B. Over-expression of the peroxisomal ascorbate peroxidase (SbpAPX) gene cloned from halophyte Salicornia brachiata confers salt and drought stress tolerance in transgenic tobacco. Mar. Biotechnol. 2014, 16, 321-332. [CrossRef]

30. Singh, N.; Mishra, A.; Jha, B. Ectopic over-expression of peroxisomal ascorbate peroxidase (SbpAPX) gene confers salt stress tolerance in transgenic peanut (Arachis hypogaea). Gene 2014, 547, 119-125. [CrossRef]

31. Tiwari, V.; Chaturvedi, A.K.; Mishra, A.; Jha, B. Introgression of the SbASR-1 gene cloned from a halophyte Salicornia brachiata enhances salinity and drought endurance in transgenic groundnut (Arachis hypogaea) and acts as a transcription factor. PLoS ONE 2015, 10, e0135541. [CrossRef]

32. Patel, M.K.; Joshi, M.; Mishra, A.; Jha, B. Ectopic expression of SbNHX1 gene in transgenic castor (Ricinus communis L.) enhances salt stress by modulating physiological process. Plant Cell Tissue Organ Cult. 2015, 122, 477-490. [CrossRef]

33. Udawat, P.; Jha, R.K.; Sinha, D.; Mishra, A.; Jha, B. Overexpression of a cytosolic abiotic stress responsive universal stress protein (SbUSP) mitigates salt and osmotic stress in transgenic tobacco plants. Front. Plant Sci. 2016, 7, 518. [CrossRef]

34. Pandey, S.; Patel, M.K.; Mishra, A.; Jha, B. In planta transformed cumin (Cuminum cyminum L.) plants, overexpressing the SbNHX1 gene showed enhanced salt endurance. PLoS ONE 2016, 11, e0159349. [CrossRef] [PubMed]

35. Udawat, P.; Jha, R.K.; Mishra, A.; Jha, B. Overexpression of a plasma membrane-localized SbSRP-like protein enhances salinity and osmotic stress tolerance in transgenic tobacco. Front. Plant Sci. 2017, 8, 582. [CrossRef] [PubMed]

36. Jha, R.K.; Patel, J.; Mishra, A.; Jha, B. Introgression of halophytic salt stress-responsive genes for developing stress tolerance in crop plants. In Halophytes and Climate Change: Adaptive Mechanisms and Potential Uses; Hasanuzzaman, M., Shabala, S., Fujita, M., Eds.; CABI: Egham, UK, 2019; p. 275. [CrossRef]

37. Tiwari, V.; Chaturvedi, A.K.; Mishra, A.; Jha, B. The transcriptional regulatory mechanism of the peroxisomal ascorbate peroxidase ( $p A P X)$ gene cloned from an extreme halophyte, Salicornia brachiata. Plant Cell Physiol. 2014, 55, 201-217. [CrossRef]

38. Tiwari, V.; Patel, M.K.; Chaturvedi, A.K.; Mishra, A.; Jha, B. Functional characterization of the tau class Glutathione-S-Transferases gene (SbGSTU) promoter of Salicornia brachiata under salinity and osmotic Stress. PLoS ONE 2016, 11, e0148494. [CrossRef]

39. Singh, V.K.; Mishra, A.; Haque, I.; Jha, B. A novel transcription factor-like gene SbSDR1 acts as a molecular switch and confers salt and osmotic endurance to transgenic tobacco. Sci. Rep. 2016, 6, 31686. [CrossRef] [PubMed]

40. Tiwari, V.; Patel, M.K.; Chaturvedi, A.K.; Mishra, A.; Jha, B. Cloning and functional characterization of the Na+/H+ antiporter (NHX1) gene promoter from an extreme halophyte Salicornia brachiata. Gene 2019, 683, 233-242. [CrossRef] [PubMed]

41. Shomer-Ilan, A.; Beer, S.; Waisel, Y. Suaeda monoica, a C 4 plant without typical bundle sheaths. Plant Physiol. 1975, 56, 676-679. [CrossRef]

42. Flowers, T.J.; Colmer, T.D. Plant salt tolerance: Adaptations in halophytes. Ann. Bot. 2015, 115, 327-331. [CrossRef]

43. Moghaieb, R.E.A.; Saneoka, H.; Fujita, K. Effect of salinity on osmotic adjustment, glycine betaine accumulation and the betaine aldehyde dehydrogenase gene expression in two halophytic plants, Salicornia europaea and Suaeda maritima. Plant Sci. 2004, 166, 1345-1349. [CrossRef]

44. Ku, M.S.B.; Cho, D.; Ranade, U.; Hsu, T.P.; Li, X.; Jiao, D.M.; Ehleringer, J.; Miyao, M.; Matsuoka, M. Photosynthetic performance of transgenic rice plants overexpressing maize $C_{4}$ photosynthesis enzymes. Stud. Plant Sci. 2000, 7, $193-204$.

45. Muthusamy, S.K.; Lenka, S.K.; Katiyar, A.; Chinnusamy, V.; Singh, A.K.; Bansal, K.C. Genome-wide identification and analysis of biotic and abiotic stress regulation of $\mathrm{C}_{4}$ photosynthetic pathway genes in rice. Appl. Biochem. Biotechnol. 2019, 187, 221-238. [CrossRef] [PubMed] 
46. Patel, M.K.; Mishra, A.; Jaiswar, S.; Jha, B. Metabolic profiling and scavenging activities of developing circumscissile fruit of psyllium (Plantago ovata Forssk.) reveal variation in primary and secondary metabolites. BMC Plant Biol. 2020, 20, 116. [CrossRef] [PubMed]

47. Pandey, S.; Patel, M.K.; Mishra, A.; Jha, B. Physio-biochemical composition and untargeted metabolomics of cumin (Cuminum cyminum L.) make it promising functional food and help in mitigating salinity stress. PLoS ONE 2015, 10, e0144469. [CrossRef] [PubMed]

48. Fiehn, O.; Kopka, J.; Dörmann, P.; Altmann, T.; Trethewey, R.N.; Willmitzer, L. Metabolite profiling for plant functional genomics. Nat. Biotechnol. 2000, 18, 1157-1161. [CrossRef]

49. Weckwerth, W. Metabolomics in systems biology. Annu. Rev. Plant Biol. 2003, 54, 669-689. [CrossRef] [PubMed]

50. Fukusaki, E.; Kobayashi, A. Plant metabolomics: Potential for practical operation. J. Biosci. Bioeng. 2005, 100, 347-354. [CrossRef] [PubMed]

51. Sharma, S.; Choudhary, B.; Yadav, S.; Mishra, A.; Mishra, V.K.; Chand, R.; Chen, C.; Pandey, S.P. Metabolite profiling identified pipecolic acid as an important component of peanut seed resistance against Aspergillus flavus infection. J. Hazard. Mater. 2021, 404, 124155. [CrossRef] [PubMed]

52. Král'ová, K.; Jampılek, J.; Ostrovsky, I. Metabolomics-Useful tool for study of plant responses to abiotic stresses. Ecol. Chem. Eng. 2012, 19, 133-161. [CrossRef]

53. Patel, M.K.; Mishra, A.; Jha, B. Untargeted metabolomics of halophytes. In Marine Omics: Principles and Applications; Kim, S., Ed.; CRC Press: Boca Raton, FL, USA, 2016; pp. 309-325. [CrossRef]

54. Tanna, B.; Mishra, A. Metabolomics of seaweeds: Tools and techniques. In Plant Metabolites and Regulation under Environmental Stress; Ahmad, P., Ahanger, M.A., Singh, V.P., Tripathi, D.K., Alam, P., Alyemeni, M.N., Eds.; Academic Press, Elsevier: Cambridge, MA, USA, 2018; pp. 37-52. [CrossRef]

55. Patel, M.K.; Mishra, A.; Jha, B. Non-targeted metabolite profiling and scavenging activity unveil the nutraceutical potential of psyllium (Plantago ovata Forsk). Front. Plant Sci. 2016, 7, 431. [CrossRef]

56. Fiehn, O. Metabolomics-the link between genotypes and phenotypes. Plant Mol. Biol. 2002, 48, 155-171. [CrossRef]

57. Arbona, V.; Manzi, M.; Ollas, C.D.; Gómez-Cadenas, A. Metabolomics as a tool to investigate abiotic stress tolerance in plants. Int J. Mol. Sci. 2013, 14, 4885-4911. [CrossRef] [PubMed]

58. Hong, J.; Yang, L.; Zhang, D.; Shi, J. Plant metabolomics: An indispensable system biology tool for plant science. Int. J. Mol. Sci. 2016, 17, 767. [CrossRef] [PubMed]

59. Obata, T.; Fernie, A.R. The use of metabolomics to dissect plant responses to abiotic stresses. Cell. Mol. Life Sci. 2012, 69, 3225-3243 [CrossRef] [PubMed]

60. Kim, J.W.; Tchernyshyov, I.; Semenza, G.L.; Dang, C.V. HIF-1-mediated expression of pyruvate dehydrogenase kinase: A metabolic switch required for cellular adaptation to hypoxia. Cell Metab. 2006, 3, 177-185. [CrossRef] [PubMed]

61. Sanchez, D.H.; Siahpoosh, M.R.; Roessner, U.; Udvardi, M.; Kopka, J. Plant metabolomics reveals conserved and divergent metabolic responses to salinity. Physiol. Plant. 2007, 132, 209-219. [CrossRef] [PubMed]

62. Colmer, T.D.; Flowers, T.J. Flooding tolerance in halophytes. New Phytol. 2008, 179, 964-974. [CrossRef]

63. Sanchez, D.H.; Pieckenstain, F.L.; Escaray, F.J. Comparative ionomics and metabolomics in extremophile and glycophytic Lotus species under salt stress challenge the metabolic pre-adaptation hypothesis. Plant Cell Environ. 2011, 34, 605-617. [CrossRef]

64. Behr, J.H.; Bouchereau, A.; Berardocco, S.; Seal, C.E.; Flowers, T.J.; Zörb, C. Metabolic and physiological adjustment of Suaeda maritima to combined salinity and hypoxia. Ann. Bot. 2017, 119, 965-976.

65. Liu, X.; Wu, H.; Ji, C.; Wei, L.; Zhao, J.; Yu, J. An integrated proteomic and metabolomic study on the chronic effects of mercury in Suaeda salsa under an environmentally relevant salinity. PLoS ONE 2013, 8, e64041. [CrossRef]

66. Li, Q.; Song, J. Analysis of widely targeted metabolites of the euhalophyte Suaeda salsa under saline conditions provides new insights into salt tolerance and nutritional value in halophytic species. BMC Plant Biol. 2019, 19, 388. [CrossRef]

67. Song, J.; Shi, W.W.; Liu, R.R.; Xu, Y.G.; Sui, N.; Zhou, J.C.; Feng, G. The role of the seed coat in adaptation of dimorphic seeds of the euhalophyte Suaeda salsa to salinity. Plant Species Biol. 2017, 32, 107-114. [CrossRef]

68. Gavaghan, C.L.; Li, J.V.; Hadfield, S.T.; Hole, S.; Nicholson, J.K.; Wilson, I.D.; Howe, P.W.A.; Stanley, P.D.; Holmes, E. Application of NMR-based metabolomics to the investigation of salt stress in maize (Zea mays). Phytochem. Anal. 2011, 22, 214-224. [CrossRef] [PubMed]

69. Wedow, J.M.; Yendrek, C.R.; Mello, T.R.; Creste, S.; Martinez, C.A.; Ainsworth, E.A. Metabolite and transcript profiling of Guinea grass (Panicum maximum Jacq) response to elevated $\left[\mathrm{CO}_{2}\right.$ ] and temperature. Metabolomics 2019, 15, 51. [CrossRef] [PubMed]

70. Kusano, M.; Fukushima, A.; Redestig, H.; Saito, K. Metabolomic approaches toward understanding nitrogen metabolism in plants. J. Exp. Bot. 2011, 62, 1439-1453. [CrossRef]

71. Alexander, A.; Singh, V.K.; Mishra, A.; Jha, B. Plant growth promoting rhizobacterium Stenotrophomonas maltophilia BJ01 augments endurance against $\mathrm{N}_{2}$ starvation by modulating physiology and biochemical activities of Arachis hypogea. PLoS ONE 2019, 14, e0222405. [CrossRef]

72. Yan, N.; Du, Y.; Liu, X.; Chu, M.J.; Shi, J.; Zhang, H.B.; Liu, Y.H.; Zhang, Z.F. A comparative UHPLC-QqQ-MS-based metabolomics approach for evaluating Chinese and north American wild rice. Food Chem. 2019, 275, 618-627. [CrossRef]

73. Kato, H.; Izumi, Y.; Hasunuma, T.; Matsuda, F.; Kondo, A. Widely targeted metabolic profiling analysis of yeast central metabolites. J. Biosci. Bioeng. 2012, 113, 665-673. [CrossRef] 
74. Yadav, S.; Mishra, A.; Jha, B. Elevated $\mathrm{CO}_{2}$ leads to carbon sequestration by modulating $\mathrm{C}_{4}$ photosynthesis pathway enzyme (PPDK) in Suaeda monoica and S. fruticosa. J. Photochem. Photobiol. B 2018, 178, 310-315. [CrossRef]

75. Yadav, S.; Rathore, M.S.; Mishra, A. The Pyruvate-Phosphate Dikinase $\left(\mathrm{C}_{4}-\mathrm{SmPPDK}\right)$ gene from Suaeda monoica enhances photosynthesis, carbon assimilation, and abiotic stress tolerance in a $\mathrm{C}_{3}$ plant under elevated $\mathrm{co}_{2}$ conditions. Front. Plant Sci. 2020, 11, 345. [CrossRef]

76. Hoagland, D.R.; Arnon, D.I. The water-culture method for growing plants without soil. Circular. Calif. Agric. Exp. Stn. 1950, 347, $1-32$.

77. Lisec, J.; Schauer, N.; Kopka, J.; Willmitzer, L.; Fernie, A.R. Gas chromatography mass spectrometry-based metabolite profiling in plants. Nat. Protoc. 2006, 1, 387. [CrossRef] [PubMed]

78. Tanna, B.; Brahmbhatt, H.R.; Mishra, A. Phenolic, flavonoid, and amino acid compositions reveal that selected tropical seaweeds have the potential to be functional food ingredients. J. Food Process. Preserv. 2019, 43, e14266. [CrossRef]

79. Worley, B.; Powers, R. Multivariate analysis in metabolomics. Curr. Metab. 2013, 1, 92-107.

80. Sairam, R.K.; Srivastava, G.C.; Saxena, D.C. Increased antioxidant activity under elevated temperatures: A mechanism of heat stress tolerance in wheat genotypes. Biol. Plant. 2000, 43, 245-251. [CrossRef]

81. Merewitz, E.B.; Du, H.; Yu, W.; Liu, Y.; Gianfagna, T.; Huang, B. Elevated cytokinin content in ipt transgenic creeping bentgrass promotes drought tolerance through regulating metabolite accumulation. J. Exp. Bot. 2011, 63, 1315-1328. [CrossRef]

82. Gill, S.S.; Tuteja, N. Reactive oxygen species and antioxidant machinery in abiotic stress tolerance in crop plants. Plant Physiol. Biochem. 2010, 48, 909-930. [CrossRef]

83. Misra, B.B.; Chen, $\mathrm{S}$. Advances in understanding $\mathrm{CO}_{2}$ responsive plant metabolomes in the era of climate change. Metabolomics 2015, 11, 1478-1491. [CrossRef]

84. Suzuki, N.; Rivero, R.M.; Shulaev, V.; Blumwald, E.; Mittler, R. Abiotic and biotic stress combinations. New Phytol. 2014, 203, 32-43. [CrossRef]

85. Zandalinas, S.I.; Mittler, R.; Balfagón, D.; Arbona, V.; Gómez-Cadenas, A. Plant adaptations to the combination of drought and high temperatures. Physiol. Plant. 2018, 162, 2-12. [CrossRef]

86. Hare, P.D.; Cress, W.A.; Van Staden, J. Dissecting the roles of osmolyte accumulation during stress. Plant Cell Environ. 1998, 21, 535-553. [CrossRef]

87. Rizhsky, L.; Liang, H.; Shuman, J.; Shulaev, V.; Davletova, S.; Mittler, R. When defense pathways collide. The response of Arabidopsis to a combination of drought and heat stress. Plant Physiol. 2014, 134, 1683-1696. [CrossRef] [PubMed]

88. Jin, R.; Wang, Y.; Liu, R.; Gou, J.; Chan, Z. Physiological and metabolic changes of purslane (Portulaca oleracea L.) in response to drought, heat, and combined stresses. Front. Plant Sci. 2016, 6, 1123. [CrossRef] [PubMed]

89. Du, H.; Wang, Z.; Yu, W.; Liu, Y.; Huang, B. Differential metabolic responses of perennial grass Cynodon transvaalensis $\times$ Cynodon dactylon $\left(\mathrm{C}_{4}\right)$ and Poa pratensis $\left(\mathrm{C}_{3}\right)$ to heat stress. Physiol. Plant 2011, 141, 251-264. [CrossRef] [PubMed]

90. Lea, P.J.; Sodek, L.; Parry, M.A.; Shewry, P.R.; Halford, N.G. Asparagine in plants. Ann. Appl. Biol. 2007, 150, 1-26. [CrossRef]

91. Suguiyama, V.F.; Silva, E.A.; Meirelles, S.T.; Centeno, D.C.; Braga, M.R. Leaf metabolite profile of the Brazilian resurrection plant Barbacenia purpurea Hook. (Velloziaceae) shows two time-dependent responses during desiccation and recovering. Front. Plant Sci. 2014, 5, 96. [CrossRef]

92. Gong, Q.; Li, P.; Ma, S.; Indu Rupassara, S.; Bohnert, H.J. Salinity stress adaptation competence in the extremophile Thellungiella halophila in comparison with its relative Arabidopsis thaliana. Plant J. 2005, 44, 826-839. [CrossRef]

93. Bendaly, A.; Messedi, D.; Smaoui, A.; Ksouri, R.; Bouchereau, A.; Abdelly, C. Physiological and leaf metabolome changes in the xerohalophyte species Atriplex halimus induced by salinity. Plant Physiol. Biochem. 2016, 103, 208-218. [CrossRef]

94. Koussevitzky, S.; Suzuki, N.; Huntington, S.; Armijo, L.; Sha, W.; Cortes, D.; Mittler, R. Ascorbate peroxidase 1 plays a key role in the response of Arabidopsis thaliana to stress combination. J. Biol. Chem. 2018, 283, 34197-34203. [CrossRef]

95. Yu, J.; Chen, L.; $\mathrm{Xu}, \mathrm{M}$.; Huang, B. Effects of elevated $\mathrm{CO}_{2}$ on physiological responses of tall fescue to elevated temperature, drought stress, and the combined stresses. Crop Sci. 2012, 52, 1848-1858. [CrossRef]

96. Zhang, S.; Zheng, X.; Reiter, R.J.; Feng, S.; Wang, Y.; Liu, S.; Jin, L.; Li, Z.; Datla, R.; Ren, M. Melatonin attenuates potato late blight by disrupting cell growth, stress tolerance, fungicide susceptibility and homeostasis of gene expression in Phytophthora infestans. Front. Plant Sci. 2017, 8, 1993. [CrossRef]

97. Arnao, M.B.; Hernández-Ruiz, J. Growth activity, rooting capacity, and tropism: Three auxinic precepts fulfilled by melatonin. Acta Physiol. Plant. 2017, 39, 127. [CrossRef]

98. Li, J.; Zeng, L.; Cheng, Y.; Lu, G.; Fu, G.; Ma, H.; Liu, Q.; Zhang, X.; Zou, X.; Li, C. Exogenous melatonin alleviates damage from drought stress in Brassica napus L.(rapeseed) seedlings. Acta Physiol. Plant. 2018, 40, 43. [CrossRef]

99. Shi, H.; Jiang, C.; Ye, T.; Ye, T.; Chan, Z. Comparative physiological, metabolomic, and transcriptomic analyses reveal mechanisms of improved abiotic stress resistance in bermudagrass [Cynodon dactylon (L). Pers.] by exogenous melatonin. J. Exp. Bot. 2015, 66, 681-694. [CrossRef] [PubMed]

100. Arnao, M.B.; Hernández-Ruiz, J. Melatonin: Plant growth regulator and/or biostimulator during stress? Trends Plant Sci. 2014, 19, 789-797. [CrossRef] [PubMed]

101. Arnao, M.B.; Hernández-Ruiz, J. Functions of melatonin in plants: A review. J. Pineal Res. 2015, 59, 133-150. [CrossRef] [PubMed]

102. Wang, Y.; Reiter, R.J.; Chan, Z. Phytomelatonin: A universal abiotic stress regulator. J. Exp. Bot. 2018, 69, 963-974. [CrossRef] 
103. Wei, J.; Li, D.X.; Zhang, J.R.; Shan, C.; Rengel, Z.; Song, Z.B. Phytomelatonin receptor PMTR1-mediated signaling regulates stomatal closure in Arabidopsis thaliana. J. Pineal Res. 2018, 65, e12500.

104. Arnao, M.B.; Hernández-Ruiz, J. Melatonin: A new plant hormone and/or a plant master regulator? Trends Plant Sci. 2019, 24, 38-48. [CrossRef]

105. Debnath, B.; Islam, W.; Li, M.; Sun, Y.; Lu, X.; Mitra, S.; Qiu, D. Melatonin mediates enhancement of stress tolerance in plants. Int. J. Mol. Sci. 2019, 20, 1040. [CrossRef]

106. Zhang, M.; Liu, W.X.; Zheng, M.F.; Xu, Q.L.; Wan, F.H.; Wang, J.; Lei, T.; Zhou, Z.Y.; Tan, J. Bioactive quinic acid derivatives from Ageratina adenophora. Molecules 2013, 18, 14096-14104. [CrossRef]

107. Yang, Y.; Wang, Y.; Jia, L.; Yang, G.; Xu, X.; Zhai, H.; He, S.; Li, J.; Dai, X.; Qin, N.; et al. Involvement of an ABI-like protein and a $\mathrm{Ca}_{2}+$-ATPase in drought tolerance as revealed by transcript profiling of a sweetpotato somatic hybrid and its parents Ipomoea batatas (L.) Lam. and I. triloba L. PLoS ONE 2018, 13, e0193193. [CrossRef] [PubMed]

108. Nadeem, M.; Mumtaz, M.W.; Danish, M.; Rashid, U.; Mukhtar, H.; Anwar, F.; Raza, S.A. Calotropis procera: UHPLC-QTOF-MS/MS based profiling of bioactives, antioxidant and anti-diabetic potential of leaf extracts and an insight into molecular docking. Food Meas. Charact. 2019, 13, 3206-3220. [CrossRef]

109. Yao, X.; Jiang, H.; Li, Y.H.; Gao, Q.; Xu, Y.N.; Kim, N.H. Kaempferol alleviates the reduction of developmental competence during aging of porcine oocytes. Anim. Sci. J. 2019, 90, 1417-1425. [CrossRef] [PubMed]

110. Tanna, B.; Mishra, A. Metabolites unravel nutraceutical potential of edible seaweeds: An emerging source of functional food Compr. Rev. Food Sci. Food Saf. 2018, 17, 1613-1624. [CrossRef] [PubMed]

111. Jha, R.K.; Patel, J.; Patel, M.K.; Mishra, A.; Jha, B. Introgression of a novel cold and drought regulatory-protein encoding CORA-like gene, $S b C D R$, induced osmotic tolerance in transgenic tobacco. Physiol. Plant. 2020. [CrossRef] 